\title{
On the Female Roles in Miss Saigon
}

\author{
Zisu Wang ${ }^{1}$ \\ ${ }^{1}$ Shandong Experimental High School, Jinan, China \\ *2076541187@qq.com

\begin{abstract}
Miss Saigon is a famous musical in New York. As a musical set in the Vietnam War, the plot is touching and moving. The discussion on the good and evil of human nature behind the music story has never stopped. Miss Saigon, Cat, The Phantom of The Opera and Les Miserables are known as the four famous dramas. They are known as "the most fascinating, affectionate and exciting musical in West London". Based on this, this paper focuses on the analysis of the female characters in Miss Saigon, analyzes the female characters from the perspectives of story background, story content and characters' feelings, and explores the emotional attitudes behind the musical.
\end{abstract}

Keywords: Female Roles; Miss Saigon; Musical

\section{INTRODUCTION}

Miss Saigon tells the love story of a Vietnamese dancer and an American soldier[1]. The story of Miss Saigon developed from the real event behind the photo, telling a former American soldier Chris and a fatherless Vietnamese prostitute Kim who met in a Saigon Hotel. The two protagonists had an unwillingly sexual relationship at the beginning, but then they fell in love with each other. Soon after, Chris was forced to withdraw from Vietnam with the U.S. military, and had to struggle with Kim for the next three years to deal with their emotional relationship. The tragic ending is that the heroine Kim does not hesitate to give up her life in exchange for a better future for her child.

Under the shell of love, the story shows the pain brought by the war, and the evil side of human nature is thought-provoking. The arrogance under the war set off all kinds of waves, with hidden dangers and fears intertwined. The fierce collision between the two civilizations, especially the contradiction between the East and the west. Miss Saigon is adapted from Puccini's opera "Madame Butterfly"[2], which is particularly prominent in characterization. Puccini is one of the representatives of Italian realistic opera composers at the end of the 19th century. His works mostly reflect the daily life of ordinary people.The female characters created by Puccini have prominent artistic characteristics, which are generally kind, beautiful and devoted to love.
Each character has been well portrayed. The audience can better feel and resonate with the plot, especially the female characters in the plot, which are very tense. From the choice of each female character, we can also see the influence of transcending the stage of art itself on fate, struggling and pursuit for oneself. In the process of appreciating Miss Saigon, we can better see the differences between eastern and western cultures, as well as different women's choices about the future of life.

\section{TWO MAIN FEMALE CHARACTERS IN MISS SAIGON}

Miss Saigon is adapted from the opera "Madame Butterfly". The main timeline of the story is in the postwar period of Vietnam[3]. It tells the story of a former American soldier Chris and a fatherless Vietnamese prostitute Kim meeting in a hotel in Saigon. The musical Miss Saigon has two acts. The first act tells the meeting, acquaintance, love and separation of Kim and Chris. The second act tells the mutual search, final meeting and tragic ending of Kim and Chris. In the two acts, in addition to the heroine Kim, there is another female character, Chris's new wife Alan. Alan also occupies an important position in the second act. As a key figure in the plot, we can clearly see the differences between the two female characters and a concrete expression of the cultural differences between the East and the West. 


\subsection{The heroine of Kim}

Kim is the heroine in the musical Miss Saigon. All the characteristics she shows attract the attention of the audience. She is firm in love and brave and strong with children. In the face of love, she refused the marriage arranged by the family. Her fiance said that "The days of all Americans and prostitutes will not be long, and their end will only be to separate and die", which also laid the groundwork for the later wandering life.

Her life is full of tragedy and suffering, but only with her persistence in love, she has been working hard. She has become a prostitute for survival and freedom. Later, she became a dancer for her children and love. She struggled to survive in society. In order to protect her children, she killed her fiance. Every day after Chris left, she was humble to survive, but she never gave up. However, in order to make her children get a better life, she chose to give up her life. Kim lived, tortured and died for love all her life.

In the whole work, Kim is incarnated into the image of mother and lover, showing us the soft and strong side of women with deep sympathy.

\subsection{The important female role of Allen}

Allen is another important female role in the musical Miss Saigon. Although she appears behind, her existence still leads the plot to a new direction. In the first act, Allen has been eager to know what the shadow around her husband's heart is. One day, they lie down together. When her husband suddenly wakes up from his sleep and sits up calls Kim's name, Allen comforts him to lie down again. At this day,she and Kim express their love for Chris in different countries.

Allen, a female character, is independent and great. She embraces everything about Chris. Even if she knows the existence of Kim, she still believes in Chris and lets Chris choose. She is frank and direct. Unlike Kim, she is sober and accessible. There are obvious differences in the cognition of love between the two female characters. Allen also sympathized with Kim and finally accepted Kim's children.

\subsection{The another female characters}

In addition to the two main female characters, there are also many female characters in the early stage of the first scene. In order to compete for the title of "Miss Saigon", they flirt in front of the soldiers. They think the winner will be drawn by the soldiers as a prize, which means that they may be taken to the United States and live a good life from then on .But even if they get the title of "Miss Saigon", they don't really get rid of their tragic task, let alone be taken to the US. Vietnam's social order during the war could not be guaranteed, just like when the United States withdrew, countless
Vietnamese crowded in front of the embassy and begged to go to the United States. The "American Dream" mapped by these female roles, the "good life" pursued and the "beautiful country" yearned for are more pitiful, and the irony is also very prominent. Maybe they are really taken away by American soldiers and can have a good life, but is the sacrifice and price really worth it?

\section{A COMPARATIVE ANALYSIS OF TWO MAIN FEMALE CHARACTERS IN MISS SAIGON}

In Miss Saigon, every female character is vividly expressed, and the contradictions and conflicts are also vividly portrayed, which can make the audience resonate better, but we can also see this rigid image of oriental women.

As a Vietnamese woman, Kim has always been in a passive position[4]. She has been conquered, manipulated, abandoned and deceived. Her only resistance is for her children. Finally, she fought with her life for the last time to fight against the injustice of fate. At the same time, she is also sending her children to the United States with "death". The play portrays a female image of love supremacy, and even dies for love. Kim is naive , pure and loyalty. Kim expressed her loyalty to love with waiting. "In the depths of my soul, there is no wind, although the flame of hope is weak."."I made a vow of love. No matter the ends of the earth will never change, he will come back to me.". This is the cry of Kim, tearing and deep in her heart. At the same time, it implies the tragic fate of gold, and the soul that has nowhere to be placed is floating.

"They can't express themselves, they can only be expressed by others." Marx used this sentence to describe the class differences, and in the script, we can also see the situation of Oriental characters in western literature. In Miss Saigon, Kim's image has always been weak and made direct criticism of the male protagonist American soldier, but Kim's female image has always relied on her lover, an American soldier, who is not friendly to this female role on many levels, but the antiwar concept behind it is thought-provoking, it is not difficult to see the content of the script creation itself.

As the newly married wife of the hero Chris, she tolerated her husband, but after learning the truth, Allen did not completely become a vassal of her husband. Although she loves her husband deeply, she took the initiative to let him make a choice. The portrayal and comparison of this task, the final choice and trend of female characters set off by contradictions and conflicts and environmental atmosphere put to a climax.

In fact, the comparison between the two female characters is also to show the cultural differences between the East and the West. Women in Vietnam and 
the United States are affected by many factors, and there are great differences in their life circumstances and life choices. The root is the long-term cultural repression. When Kim first resisted the arrangement of his parents and went to prostitutes, her life seems to have changed. Her pursuit of love and freedom finally led her to tragedy. The heroine's loyalty to love is moving. This persistence and waiting are the core of the whole play. The same is true for the female characters in Mrs. butterfly[5]. After waiting for three years, she chose to commit suicide. Mrs. butterfly is a Japanese geisha and even betrayed her religious beliefs. This conflict is more intense.

Kim's character image is complex. There are both resistance and obedience in her life track. She is silent and warm. From the development of the two scenes, Kim's character changes very violently, but each of these changes fits the reality. In the teenage period after escaping marriage, she fell in love with Chris and married him without hesitation despite feedback and persuasion. She naively believed the promise made by the American soldier and waited for three years without hesitation. This stubbornness is loyalty to marriage and love. Three years later, she took her children to Bangkok to be a singer and find her husband. Under such circumstances, she still firmly chose love. The bumps and hardships along the way, enduring the devastation brought by life without complaint, just because she has commitment to love in the hearts. No matter how old the threat and inducement were, she did not hesitate or doubt Chris's commitment to her. "Chris will come back to pick us up, I am his wife, and we have the oath of love". At last, she put on their "wedding dress" and saw her husband's new wife. At this time, her hope for the future was destroyed. She was unwilling to admit that her husband had betrayed her and abandoned her. She still chose to tell their children that his father loved him and his mother loved him very much. Finally, she went to death with a decisive attitude.

From beginning to end, she didn't have the courage to pursue an independent and individual life, but she was resolute. She chose her own destiny, and she chose a different future for her children. Even if the future might not be beautiful, she had no other way. "Her body will not rot in the soil, but in the sky like a bird." she made the most important choice in her life. In fact, there is obvious Orientalism[6] in the shaping of her character. It is a Western way of thinking or cognitive system for "Oriental people", and it is the Oriental people and oriental culture they understand.

\section{AN ANALYSIS OF THE MAIN FEMALE CHARACTERS IN MISS SAIGON}

If readers want to really understand the character image of a literary work, they must first understand the historical and cultural background of the literary work.

In western society, the status of women has been changing. As early as the Middle Ages, due to low productivity and low production efficiency, reproduction was an important condition for the survival of Western society at that time, and women were promoted to the throne. For example, the goddess Athena in Greek mythology symbolized bravery and good war, and mastered the control of the world. With the development and progress of productive forces, the status of women has also changed significantly. During this period, there are many images of female slaves in literary works.

After the Middle Ages, with the emergence of the feudal landlord class, women's awareness of sovereignty was significantly enhanced and women's rights were increasing, but women's overall status still needed to be further improved, which was also clearly reflected in foreign literary works.

Judging from the broadcast history of Miss Saigon, a large number of Asians boycotted when it was first broadcast. However, compared with the negative portrayal of female characters, the main body of the musical is still centered on anti-war, and more people are criticizing American soldiers. The Vietnam War brought not only a national coup, but also the painful condolences of tens of millions of Vietnamese people. Just as in the second half of the musical, Chris's friend, an American soldier who "bought" Kim for Chris, actively organized to rescue the abandoned children under the war. These children are the mixed race children born of American soldiers and Vietnamese women. They were discriminated against by people. They were born afraid to be "human". There are far more left over from the Vietnam War. There are women with the same fate as Kim in Miss Saigon who live, torture and die for love.

"The image is based on and higher than the character, and the image is based on the development of the character drama." the character is the basic element of the musical, and the character and psychological process are the core of the musical. In fact, the scene switching times of Miss Saigon are not many, and the description of the stage scene is also very few. The key lies in the dialogue of the actors. Each detail is handled in place. Each scene gives the audience unlimited space to imagine, and each actor performs vividly, which is the charm of the classic works of Miss Saigon. Selecting this special period has a relatively strong political color, liberates the research object from the elegant culture and traditional literary classics[7], and pays attention to the 
research of popular culture and mass media. Since then, the phenomenon of mass culture has ascended in the academic. It can be said that the character and the plot complement each other. In the process of musical performance, in addition to the control of pronunciation and singing skills, the corresponding artistic treatment of songs should be carried out.

The characters in each musical have their own independent personality characteristics, which will be affected by the background of the times, plot and so on. Therefore, if you want to really understand the characters in the musical, you must first understand the era background of Miss Saigon and the characters related to Miss Saigon .

It can be seen from the above that the opening of Miss Saigon takes place in a Vietnamese brothel, and the people in the brothel are American soldiers and Vietnamese prostitutes. "Miss Saigon" is the "pastime" of these American soldiers. For these girls, American soldiers are more like the key to a new world. All girls welcome soldiers and fear soldiers. Therefore, American soldiers are absolutely confident and full of power in this scene. Here, American soldier Chris met Kim for the first time. At this moment, he is not only the side to be displayed as an American soldier, but also to show the development of two people's love and show that two sad hearts collide with each other. This kind of love is based on mutual pain, seeking comfort and sympathy, but it also foreshadows the later tragedy, which originated from the devastation of war.

Miss Saigon tells the love story of a Vietnamese dancer and an American soldier. The story of Miss Saigon developed from the real event behind the photo, telling a former American soldier Chris and a fatherless Vietnamese prostitute Kim who met in a Saigon Hotel. The two protagonists had an unwillingly sexual relationship at the beginning, but then they fell in love with each other. Soon after, Chris was forced to withdraw from Vietnam with the U.S. military, and had to struggle with Kim for the next three years to deal with their emotional relationship. The tragic ending is that the heroine Kim does not hesitate to give up her life in exchange for a better future for her child. This story is full of strong Orientalism. Yellow women can sacrifice indefinitely for love, even if they sacrifice their lives. In the discussion of postcolonialism and Orientalism, the plot of Miss Saigon shows that the west looks at the Oriental world with their eyes. The attitude that American soldiers invade Oriental women, but Oriental women are powerless makes people angry. Chinese people generally like happy endings, and this musical has a strong pessimistic color, which is why Miss Saigon is not well-known in China.

\section{CONCLUSION}

To sum up, there are two main female characters in Miss Saigon, one is Kim, a Vietnamese prostitute, and the other is Chris's later wife Alan. The two women live in different backgrounds, grow up in different environments, and accept different cultural ideas, so that their final fate is very different.The lives of the two women are different and the final outcome is not the same. The harm of war to human society is incalculable. Up to now, there are still many people suffering from war in this world. The tragic fate of love comes from the turbulent society. The fragmented country can not bring national stability. In Kim's tragic life, all of them declare the harm and pain brought by war. From the comparison of the two women's ways of thinking, it is not difficult to see the differences. No one knows whether Kim's stubbornness and persistence really make sense, but this is her choice, from which we can also see the discussion of postcolonialism and orientalism.

\section{REFERENCES}

[1] Behr, E. , M. Steyn , and CM Schönberg. The story of Miss Saigon. Arcade Pub. 1991.

[2] Sariarslan, M. . "THE ISSUE OF ORIENTALISM IN GIACOMO PUCCINI'S MADAME BUTTERFLY AND DAVID HENRY HWANG'S M. BUTTERFLY." Electronic Turkish Studies (2016).

[3] Kim, Esther Songie. . Asian American theatre history from the $1960 \mathrm{~s}$ to 1990s: Actors, playwrights, communities, and producers.. Diss. The Ohio State University. 2000.

[4] Zhu, H. P. , L. He , and S. O. Art . "The Orientalism In the Musical Opera Miss Saigon." Journal of East China University of Technology(Social Science) (2017)

[5] Bayri, S. . "OPERA UNDER THE INFLUENCE of ORIENTALISM: GIACOMO PUCCINI'S MADAME BUTTERFLY OPERA AS an EXAMPLE." Online Journal of Music Sciences (2019):73-85.

[6] Said, E. W. . "Orientalism: Western Conceptions of the Orient." harmondsworth (1978).

[7] Bongie, Chris, and R. J. C. Young . "Postcolonialism: An Historical Introduction." Nations \& Nationalism 9.3(2010):627-628. 